\title{
PERAN AGAMA ISLAM \\ DALAM PEMBENTUKAN PENDIDIKAN KARAKTER USIA REMAJA
}

\author{
Siti Maryam Munjiat \\ Fakultas Ilmu Tarbiyah dan Keguruan \\ Institut Agama Islam Negeri Syekh Nurjati Cirebon \\ Email: sitimaryammunjiat@gmail.com
}

\begin{abstract}
ABSTRAK
Masa remaja merupakan masa perkembangan anak yang digolongkan dalam tingkat pendidikan masa usia MTs-MA, kemudian digolongkan lagi menjadi remaja awal umur 12-15 dan remaja akhir umur 15-20, seperti dikutip dari BKKBN. Dari penggolongan ini bahwa masa remaja adalah masa peralihan dari masa kanak-kanak ke masa remaja yang secara psikologi masa remaja merupakan masa perkembangan, di mana anak sudah belajar membuat pilihan dan menentukannya. Penentuan pilihan dan keinginan si anak membutuhkan pendamping untuk mengawal perjalanan si anak tersebut baik berupa keluarga, masyarakat sekitar serta suplemen lain berupa bacaan dan pemerolehan pengetahuan yang didapat. Banyak remaja terjebak pada pilihan dan keinginannya yang selalu harus dipenuhi kemudian lepas kendali dan diklaim jelek oleh norma masyarakat dan agama. Pada masa remaja juga menampilkan indikator karakter yang belum mapan sedangkan kemapanan karakter terlihat setelah ada pembiasaan sikap dan perilaku yang dibarengi kontrol keluarga dan sosial serta realisasi dari pengetahuan baik umum maupun agama dalam keseharian (internalisasi). Kontribusi agama dalam menentukan sikap dan perilaku juga sangat signifikan yang kemudian dinamakan etika, akhlaq, dan karakter. Tidak ada agama yang mengajarkan kejelekan atau keburukan sikap. Islam merupakan agama yang disepakati sebagai agama kompilasi dari agama-agama pendahulunya yang terangkum dalam al-Quran dan dijelaskan Hadis Nabi.
\end{abstract}

Kata Kunci: Karakter, Remaja, dan Pendidikan Islam

Al-Tarbawi Al-Haditsah: Jurnal Pendidikan Islam

Vol. 3, No. 1, Juni 2018 


\begin{abstract}
The early adolescent is the children period that classify in education grade, which is started from secondary to senior high school, and grouped in early teenager who is 12-15 years old and teenager 15-20 years old as stated by BKKBN. From this classification that the early adolescent is a changing period fromchildhood to adolescent which is in psychology the adolescent is development period, where the children have learned to make a choice and determine it. The choice determining and their eagerness need the guider who guides their ways, such as family, society, and other supplement as reading book to increase the knowledge. Many tenagers are trapped by theirchoices and eagerness, which is should be accepted and loose liberally and be worst claimed by the society and religion. In early adolescent shows also indicator of unstable character, meanwhile character shows after habitual action and stable attitude from family and society controlling with the realization of the sciens and religion knowledge in routines religion contribution determines the attitude and moral significantly, the which is named attitude, character and moral. There is no religion teaches a worst attitude Islam as acommitment religion as compilation of predecessor religions which written in alQuran explained in propet hadits.
\end{abstract}

Keywords: Character, teens, and Islamic Education 


\section{A. Pendahuluan}

Peran keluarga dalam mengarahkan emosi remaja-usia MTs-MA sangatlah penting karena pada anak usia remaja mulai terlihat pilihan-pilihan subjektif dan keputusan dalam bersikap ketika menghadapi masalah. Faktor eksternal seperti bahan bacaan baik visual maupun nonvisual sangat memberi kontribusi dalam pembentukan karakter remaja sehingga bukan hal yang tidak mungkin remaja semakin sulit dalam pengendalian emosi karena tersulut oleh media informasi yang agitatif bahkan provokatif. Di sinilah peran pendamping dalam mengarahkan remaja sangat dibutuhakan sehingga ada kontrol positif ketika remaja terus tumbuh dan berkembang ${ }^{1}$ dalam perjalanannya. Demikian juga halnya peran agama dalam menentukan perjalanan remaja yang terus tumbuh dan berkembang, yaitu suatu kebenaran vertikal anatara makhluk dan tuhannya. Dalam hal ini adalah agama Islam ketika menyikapi karakter atau disebut dengan akhlak. Sebagaimana nabi Muhammad diutus sebagai rasul tidak lain adalah untuk menyempunakan akhlak. ${ }^{2}$

Kehidupan seseorang berbeda pola hidupnya, karena manusia sudah ditakdirkan dalam keadaan yang berbeda beda, dalam kehidupan yang realistis ini ada berbagai macam emosi dari berbagai macam orang, karena sejatinya manusia diberi akal dan nafsu untuk membedakan dari makhluk lainnya seperti jin, dan hewan. Dari dasar itu pula yang membedakan kehidupan manusia yang beragam, dan emosi seseorang pun silih berganti, ada kalanya ketika sedang marah, sedang senang, maupun bahagia, maka hal ini dapat mendasari bahwa emosi seseorang dapat menjadi pengacu dari sistem kehidupan mereka yang beragam, karena ketika seseorang sedang mengalami ketidakbahagiaan dalam diri seseorang, maka dapat pula berpengaruh pada lingkungan mereka, karena setiap orang dibekali rasa empati terhadap sesama manusia, dan hal ini pun dapat berpengaruh pula pada kegiatan belajar mengajar di kelas, entah itu sebagai mahasiswa, murid biasa, bahkan murid privat sekalipun dan ketika mereka dalam kondisi yang

\footnotetext{
${ }^{1}$ Pertumbuhan dan perkembangan adalah hal yang bersamaan dalam kehidupan manusia namun kedua istilah tersebut tidak sama, pertumbuhan lebih ke arah fisik yaitu proses perubahan jasmaniyang terjadi sampai mencapai kematangan fisik yang bersifat kuantitatif yang dialami oleh individu yang satu dengan yang lain berbeda. Sedangkan perkembangan berupa psikis, mental, rohaniah, memiliki pola-pola tersendiri yang khas yang hanya bisa diamati tanpa bisa diukur.

${ }^{2}$ HR. Bukhari dalam Adabul Mufrad: 273
} 
tidak tenang karena banyak hal, seperti galau, marah, ataupun sakit, maka dapat dipastikan emosional orang tersebut akan berpengaruh pada yang lainnya.

Dalam kehidupan yang realistis ini emosi terkadang sulit untuk dikendalikan, sedangkan pengaruh mausia pada era modern seperti ini adalah era di mana semua orang mulai menunjukan bahwa ego lah yang terpenting, karena pada era modern ini manusia akan mempunyai pemikiran bagaimana jika seseorang akan melakukan aktivitasnya dalam begitu nyaman hanya dengan duduk di belakang meja dan mengatur-ngatur saja. Maka hal tersebut dapat menjadikan dasar bahwa emosional seseorang akan berubah yang sebelumnya senang menjadi tidak senang ketika orang yang dijadikan bawahannya mendapat tekanan yang amat besar dari emosional orang yang lebih berkuasa di atasnya.

Laju pertumbahan penduduk Indonesia yang kian menambah dan masalah ini pula dapat menyebabkan gangguan emosional diri seseorang remaja karena mereka merasa kurang mempunyai keleluasaan daerah nyaman yang dikarenakan padatnya penduduk yang ada di lingkungan sekitarnya, mereka mempunyai emosi yang kurang tersalurkan dengan benar, dan hal ini pula terjadi dalam masalah kependidikan yang berdampak negatif pada hasil belajar dan kreasi siswa.

Dalam pengaruh kurangnya penyaluran emosional dalam diri remaja, ini akan membuat emosional diri remaja semakin meluap-luap, karena kejiwaan yang labil pada masa remaja akan berdampak negatif pada remaja itu sendiri seperti dengan tawuran, iseng, corat-caret, minuman, bahkan obat-obatan. Dengan dalih mencari jati diri, remaja terus melakukan percobaanpercobaan yang banyak tidak diketahui oleh pendamping atau teman dekat yang mngawasi atau mengontrol bahkan teman dekat sendiri bisa terpengaruh mengikuti gaya dan actionnya.

Pada masalah tertentu pula bukan hanya di sekolah yang melatarbelakangi masalah emosional dalam diri seseorang, melainkan pada kondisi keluarga yang tidak seimbang, kurangnya peran ayah yang biasa dikatakan fatherless ${ }^{3}$, hal ini berdampak pada anak dengan resiko negatif, diantaranya gangguan kelakuan sosial, peningkatan masalah psikologi dan

3 fatherless adalah kurangnya perhatian anak dari orang tuanya dengan berbagai faktor, seperti kesibukan orang tua yang tidak bisa bersentuhan langsung dengan anaknya, ditinggalnya anak pergi ke luar negeri seperti menjadi Tenaga Kerja Luar, termasuk juga diakibatkan perceraian kedu orang tuanya yang mengakibatkan pelimpahan tanggung jawab dalam mengurusi anak yang tidak jelas (hak asuh).

\section{Al-Tarbawi Al-Haditsah: Jurnal Pendidikan Islam}

Vol. 3, No. 1, Juni 2018 
kurang keyakinan diri sendiri. ${ }^{4}$ dan pembelajaran orang tersebut, sebagai contoh yaitu anakanak punk dan berandalan yang ada di jalanan, mereka melakukan perbauatan yang jahat bisa dipengaruhi karena kurangnya perhatian terhadap mereka dari orang tua mereka, yang kemudian mereka mencari teman yang sejalan dengan mereka dan membuat grup-grup tertentu untuk menunjukkan sikap-sikapnya yang menurut anggapan kelompoknya sebagai tindakan yang lumrah dan wajar.

Adapun menurut Daniel goleman berpendapat bahwa emosi merujuk pada suatu perasaan dan pikiran yang khas, suatu keadaan biologis dan psikologis dan serangkaian kecenderungan untuk bertindak. Emosi pada dasarnya adalah dorongan untuk bertindak. Biasanya emosi merupakan reaksi terhadap rangsangan dari luar dan dalam diri individu. Sebagai contoh emosi gembira mendorong perubahan suasana hati seseorang, sehingga secara fisiologi terlihat tertawa, dan emosi sedih mendorong seseorang berperilaku menangis 5

Sedangkan emosi pun dibahas dalam al - qur'an pada Q.S (An - Nahl : 58) yang artinya: "padahal apabila mereka diberi kelahiran (anak perempuan) wajahnya menjadi hitam (merah padam), dan dia sangat marah."6

Dilihat dari keterangan di atas, maka emosi terbagi menjadi dua macam yaitu emosi positif dan emosi negatif. Emosi positif (emosi yang menyenangkan), yaitu emosi yang menimbulkan perasaan positif pada orang yang mengalaminya, di antaranya adalah cinta, sayang, senang, gembira, kagum dan sebagainya. Emosi negatif (emosi yang tidak menyenangkan), yaitu emosi yang menimbulkan perasaan negatif pada orang yang mengalaminya, seperti sedih, marah, benci, takut dan sebagainya.Emosi positif adalah emosi yang harus dipupuk dan dikembangkan, sedangkan emosi negatif hendaklah diminimalkan atau dikendalikan sehingga ekspresinya tidak meledak-ledak. ${ }^{7}$

\footnotetext{
${ }^{4}$ Faridah Idris, Membesarkan Anak Hebat dengan Susu Ibu (Malaysia: PTS Milenia SDN, 2013 ), 73.

${ }^{5}$ Daniel Goleman, Kecerdasan Emosional (Jakarta: Gramedia Pustaka, 2002), 411.

${ }^{6}$ Al Qur'an dan Terjemahannya (Madinah: Mujamma' al Malik Fahd LiThiba'atal Mushaf, 1415H), 410.

${ }^{7}$ http://www.duniapsikologi.com/emosi
} 


\section{B. Problematika Remaja}

Masa remaja adalah masa peralihan yang ditempuh oleh seseorang dari kanak-kanak menuju dewasa. Dapat dikatakan, bahwa masa remaja adalah perpanjangan masa kanak-kanak sebelum mencapai masa dewasa.

Masa remaja adalah masa yang penuh kontradiksi. Sebagaian orang mengatakan masa remaja adalah masa energik, heroik, dinamis, kritis, dan masa yang paling indah, tetapi ada pula yang menyebutkan bahwa masa remaja sebagai masa badai dan topan, masa rawan dan masa nyentrik. Masa remaja termasuk masa yang sangat menentukan, karena pada masa ini mereka mengalami banyak perubahan pada fisik dan psikisnya. Terjadinya perubahan kejiwaan menimbulkan kebingungan di kalangan remaja, sehingga masa ini disebut sebagai periode strum and drang. Mereka mengalami penuh gejolak emosi dan tekanan jiwa, sehingga mudah menyimpang dari aturan dan norma-norma sosial yang berlaku di kalangan masyarakat.

Masa remaja menurut sebagian orang, merupakan masa yang paling indah, karena masa tersebut adalah masa yang membuat mereka dapat menghabiskan waktunya tanpa ada yang menghalanginya. Masa remaja juga merupakan masa seseorang mencari jati dirinya dengan berbagai cara, tingkah laku, sikap, yang kadang-kadang tidak dapat dikontrol dan dikendalikan akan menjurus pada suatu hal yang negatif. ${ }^{8}$

Remaja adalah masa peralihan atau perobahan dari anak -anak kedewasa, pada usia remaja tumbuh percaya diri (self esteem) karena konsep dirinya sendiri yang meliputi perasaannya, diri dan tubuh yang dimilikinya. Self esteem ini akan berpengaruh besar terhadap apapun yang dilakukannya dan apabila orang tua mengarahkannya ke hal yang bersifat positif, maka remaja akan berbuat apa yang disenanginya tanpa memikirkan resiko, kemudian menurut Mukhtar dan kawan-kawan mendefinisikan remaja sebagai masa peralihan dari masa anak-anak ke masa dewasa, diawali dengan masa puber,yaitu proses perubahan fisik yang di tandai dengan kematangan seksual, kognisi dan sosial yang saling berkaitan satu dengan lainnya. ${ }^{9}$

Kategori remaja ketika digolongkan dalam usia sekolah menurut berbagai pendapat dan para ahli adalah usia madrasah Tsanawiyah sampai madrasah Aliyah, dalam Islam

\footnotetext{
${ }^{8}$ Popi Sopiatin dan Sohari Sahrani, Psikologi Belajar dalam Perspektif Islam (Bogor: Ghalia Indonesia, 2011), 110.

${ }^{9}$ Mukhtar, Konsep Diri Remaja (Jakarta : Rakastasmasta, 2001), 13.
} 
dikenal dengan masa baligh. ${ }^{10}$ Pertumbuhan akal merupakan hal yang abstrak dan berproses sejalan dengan perkembangan waktu sampai batas kesempurnaannya. Perubahan ini merupakan tanda atau batas yang konkret unsur baligh yang memisahkan anatara kesempurnaan dan kekurangan akal pada saat sampai batas usia itulah taklif mulai berlalu.

Rentang usianya yang panjang (sejak dalam kandungan sampai dengan usia lanjut), fase usia manusia dapat dibagi dalam 4 kelompok, yaitu kanak-kanak, remaja, dewasa, dan tua. Remaja adalah tahapan usia yang datang setelah masa kanak-kanak berakhir yang ditandai dengan cepatnya pertumbuhan fisik. Pertumbuhan cepat yang terjadi pada tubuh remaja luar dan dalam itu membawa akibat yang tidak sedikit terhadap sikap perilaku, kesehatan, serta kepribadian remaja.

Tabel indikasi usia remaja

\begin{tabular}{|l|l|}
\hline No. & \multicolumn{1}{|c|}{ Ciri khusus remaja } \\
\hline 1. & Perasaan dan emosi remaja tidak stabil \\
\hline 2. & Mengenai status remaja masih sangat sulit ditentukkan \\
\hline 3. & Kemampuan mental dan daya pikir mulai agak sempurna \\
\hline 4. & Hal sikap dan moral, menonjol pada menjelang akhir masa remaja awal \\
\hline 5. & Remaja awal adalah masa kritis \\
\hline 6. & Remaja awal banyak masalah yang dihadapi \\
\hline
\end{tabular}

Masa transisi ini, remaja menjalani badai dan topan dalam kehidupan, ketidakstabilan perasaan dan emosinya tersebut nampak jelas dalam berbagai sikap, sehingga perhatian, bimbingan dari orangtua, guru dan masyarakat sangat penting.

H. Syamun Yusuf LN mengemukakan, bahwa terdapat beberapa perkembangan pada masa remaja, di antaranya sebagai berikut:
a. Perkembangan Fisik
b. Perkembangan Intelektual
c. Perkembangan Emosi ${ }^{11}$

${ }^{10}$ Masa baligh adalah masa pubertas yang ditandai dengan keluarnya sperma bagi laki-laki baik melaui mimpi atau unsur sengaja seperti onani, berumur 15 tahun bagi laki-laki dan sejak umur 9 tahun bagi perempuan yang ditandai dengan menstruasi -keluar darah kotor dari rahim lamanya sampai 7 hari. Seperti dijelaskan dalam Syaikh Muhammad Nawawi bin Umar al-Bantani, Kasyifatus Saja (Beirut: Dar Ibn Hazm, 2011), 16.

${ }^{11}$ Popi Sopiatin dan Sohari Sahrani, Psikologi Belajar 115.

\section{Al-Tarbawi Al-Haditsah: Jurnal Pendidikan Islam}

Vol. 3, No. 1, Juni 2018 
d. Perkembangan Sosial

e. Perkembangan Moral

f. Perkembangan Kepribadian

Fase remaja ini adalah saat yang paling penting bagi perkembangan dan pengalaman baru tempat terjadinya perubahan kepribadian pada masa remaja meliputi:

1. Perolehan pertumbuhan fisik yang menyerupai dewasa.

2. Kematangan seksual yang disertai dengan dorongan-dorongan dan emosi baru.

3. Kesadaran terhadap diri sendiri, keinginan untuk mengarahkan diri dan mengevaluasi kembali tentang standar (norma) tujuan cita-cita.

4. Kebutuhan akan persahabatan yang bersifat heteroseksual, berteman dengan pria wanita.

5. Munculnya konflik sebagai dampak dari masa transisi anatara masa anak dan masa remaja.

g. Perkembangan Kesadaran Agama. ${ }^{12}$

Begitupun dengan remaja dalam kehidupan sehari-hari, sering dihadapkan pada problem atau masalah-masalah tersebut. Secara garis besar, problem yang dihadapi remaja dalam kehidupannya, Menurut Zakiah Darajat adalah sebagai berikut.

1. Problem yang Berhubungan dengan Pertumbuhan Jasmani (usia13-16 tahun)

2. Problem yang Timbul Berhubungan dengan Orang tua

3. Problem yang Berhubungan dengan Sekolah dan Pelajaran. ${ }^{13}$

4. Problem Pribadi

Sedini mungkin problem-problem remaja tersebut harus diminimalisir dengan berbagai upaya, sehingga nantinya terwujud para remaja yang sehat jiwa dan raganya.

\section{Faktor-faktor Yang Mempengaruhi Kepribadian Remaja}

a. Teori Insting

Teori Insting ini dalam buku psikologi sosial karangan Bimo Walgito disebutkan pertama kali dipelopori oleh Medougall, seorang pelopor psikologi sosial. Medougall berpendapat "Kepribadian itu di sebabkan karena insting". Dengan demikian diketahui bahwa

${ }^{12}$ Popi Sopiatin dan Sohari Sahrani, Psikologi Belajar 117.

${ }^{13}$ Popi Sopiatin dan Sohari Sahrani, Psikologi Belajar 120.

\section{Al-Tarbawi Al-Haditsah: Jurnal Pendidikan Islam}

Vol. 3, No. 1, Juni 2018 
kepribadian remaja dapat di pengaruhi oleh insting. Teori ini menilai bahwa setiap kepribadian manusia didasarkan atas insting yang dibawa manusia sejak lahir.

b. Teori Dorongan (Drive Theory)

Teori ini bertitik tolak pada pandangan bahwa organisme itu mempunyai dorongandorongan atau drive tertentu. Bila organisme ini mempunyai kebutuhan, dan organisme ini ingin memenuhi kebutuhannya maka akan terjadi ketegangan dalam diri organisme itu. Bila organisme berkepribadian dan dapat memenuhi kebutuhannya, maka akan terjadi pengurangan atau reduksi dari dorongan tersebut.

c. Teori Insentif (Insentive Theory)

Hampir sama dengan teori dorongan bahwa kepribadian menurut teori insentif berkenaan dengan adanya beberapa hadiah yang diberikan pada seseorang. Teori ini berpendapat bahwa kepribadian organisme itu disebabkan karena adanya insentif. Dengan insentif akan mendorong organisme berbuat dan berkepribadian. Insentif (reinforcement) yang positif adalah berkaitan dengan hadiah yang dapat membuat oranganisme berbuat, sedangan reinforcement negatif berkaitan dengan hukum akan menghambat organisme. Ini berarti kepribadian timbul karena adanya insentif.Meski ada perbedaan antara insentif positif dengan negatif namun, perbedaan kategori tersebut hanyalah pada batas untuk mengenal bentuk insentif yang tidak selamanya harus diartikan positif. Karena, hukuman menurut teori insentif adalah salah satu aspek yang dapat mendorong seseorang berkepribadian.

d. Teori Atribusi

Teori atribusi lebih menekankan pada faktor-faktor perubahan kepribadian dilihat dari pengaruh faktor internal dan faktor eksternal. Teori ini di kemukakan oleh Fritz Heider bahwa : "pada dasarnya kepribadian manusia itu dapat atribusi internal, tetapi juga dapat atribusi eksternal". Faktor internal berkenaan dengan fisiologis dan faktor eksternal adalah berupa pengalaman, situasi, norma-norma, hambatan dan pendorong. Kedua faktor ini saling berinteraksi dapat di bedakan namun tidak dapat dipisahkan.

e. Teori Kognitif

Kepribadian seseorang dapat didasarkan pada pertimbangan fungsional dan kemanfaatan. Sesuatu yang bermanfaat dalam hidup akan dipilih dan pilihan ini akan mendorong seorang berprilaku. Teori ini menyatakan bahwa apabila seseorang harus memilih

\section{Al-Tarbawi Al-Haditsah: Jurnal Pendidikan Islam}

Vol. 3, No. 1, Juni 2018 
kepribadian yang mesti dilakukan, maka yang bersangkutan akan memilih alternatif kepribadian yang akan membawa manfaat yang sebesar-besarnya. ${ }^{14}$

Singkatnya yang dapat penulis fahami bahwa faktor yang mempengaruhi kepribadian seorang remaja itu ada faktor internal yaitu berupa insting dan dorongan dari dalam dirinya yang membuat dia berkembang dan faktor eksternal seperti halnya pengalaman, pengaruh lingkungan yang menyangkut norma-norma, adat dan kebiasaan kebiasaan serta pengaruh teman sebaya, dari kedua faktor itu akan diproses dan dikonstruksikan kemudian ditampilkan dalam tingkah laku sehari harinya yang masih kasar dan belum terbina,maka dari itu perlu pembinaan kepribadian .

\section{Pembinaan Kepribadian Remaja}

Proses pembinaan remaja sangat erat kaitannya dengan dengan pendidikan yang berlangsung dalam rumah tangga. penerapannya haruslah mempertimbangkan fase-fase perkembangan.

Kedudukan remaja dalam keluarga adalah kondisi alamiah yang dialami oleh setiap anak manusia. Artinya secara kodrati, remaja memiliki keluarga sebagai tempat bersosialisasi. Lingkungan keluarga merupakan lingkungan pertama dimana remaja mendapat pendidikan dari orangtuannya secara langsung maupun tidak langsung.

Peranan orang tua sebagai pendidik pada hakekatnya adalah upaya menjawab kebutuhan dasar anak dalam kehidupannya. Beberapa aspek yang dibutuhkan anak yakni kebutuhan mencintai dan dicintai, kebutuhan perlindungan dan rasa aman, kebutuhan akan bimbingan, kebutuhan untuk diakui dan kebutuhan akan disiplin. Metode Pendidikan Islam dalam keluarga yang dapat dilakukan oleh orang tua, yakni:

1. Mendidik melalui keteladanan yakni orang tua memberikan contoh kepribadian yang baik untuk diikuti oleh anak

2. Mendidik melalui kebiasaan yakni dengan mengarahkan anak melakukan sesuatu yang baik secara rutin dan berkesinambungan

3. Mendidik melalui nasihat dan cerita yakni orang tua hendaknya senantiasa membimbing, mengarahkan anak melalui pemberitahuan baik secara langsung maupun tidak langsung

${ }^{14}$ Herman, Remaja dalam Presfektif Pendidikan Islam. Jurnal Al-Izzah. Vol. 10 No.1. 2015. 59-61. 
4. Mendidik melalui disiplin, dalam hal ini anak diarahkan melakukan aktifitasnya dengan jalan menegakkan aspek disiplin dan bertanggung-jawab

5. Mendidik melalui partisipasi yakni orang tua secara bersamasama melakukan aktifitas yang berhubungan dengan pembentukan kepribadiannya

6. Mendidik melalui pemeliharaan yakni dengan memberikan fasilitas dan kesejahteraan yang dibutuhkan anak dalam kehidupannya. ${ }^{15}$

\section{E. Pendidikan Islam.}

Anugerah Tuhan yang diberikan pada manusia adalah diberinya akal yang digunakan sebagai pembeda antara yang salah dan yang benar. Akan tetapi, dalam optimalisasinya akal membutuhkan bimbingan yang disebut dengan pendidikan. Pendidikan adalah bimbingan secara sadar oleh pendidik kepada terdidik terhadap perkembangan jasmani dan rohani si terdidik menuju kepribadian yang lebih baik, yang pada hakikatnya mengarah pada pembentukan manusia yang ideal. ${ }^{16}$

Agama Islam adalah agama universal yang mewajibkan pada umatnya berupa pendidikan karena dengan pendidikan manusia memperoleh bekal kehidupan yang baik dan terarah. $^{17}$

Beberapa perolehan yang didapat dari pendidikan Islam adalah:

1. Sumber Ilmu.

Karunia Allah yang cukup besar yang dianugerahkan kepada manusia ialah kemampuan berbahasa sekaligus sebagai pembeda antara manusia dengan binatang, di mana manusia mempunyai kemampuan mempelajari berbagai bahasa. Bahasa merupakan instrumen pokok bagi manusia dalam berpikir, memperoleh pengetahuan yang manghasilkan berbagai macam ilmu pengetahuan.

Bahasa dalam kapasitasnya sebagai simbol-simbol konsepsi, memungkinkan manusia memperoleh semua konsepsi dalam pemikirannya secara simbolik. Yang demikian itu dapat membantu manusia merealisasikan kemajuan yang menakjubkan dalam memperoleh pengetahuan serta menghasilkan berbagai ilmu pengetahuan dan ketrampilan yang beragam.

\footnotetext{
${ }^{15}$ Herman, Remaja dalam Presfektif Pendidikan Islam, AL-IZZAH Vol. 10 No. 1, Juli 2015, 62.

${ }^{16}$ Abudi Nata, Filsafat Pendidikan Islam (Jakarta: Gaya Media Pratama, 2013), 101.

${ }^{17}$ Zuhairini, Filsafat Pendidikan Islam (Jakarta: Bumi Aksara, 2009), 98.
} 
Dengan demikian dapat dipahami, bahwa masalah Pendidikan dalam Islam sebenarnya telah dimulai semenjak adanya manusia, yaitu Adam As dan Hawa As. sebagaimana firman Allah Swt dalam Surah al-Baqarah: 31-32.

Artinya: Dan dia mengajarkan kepada Adam nama-nama (benda-benda) seluruhnya, Kemudian mengemukakannya kepada para malaikat lalu berfirman: "Sebutkanlah kepadaKu nama benda-benda itu jika kamu mamang benar orang-orang yang benar!" Mereka menjawab: "Maha Suci Engkau, tidak ada yang kami ketahui selain dari apa yang Telah Engkau ajarkan kepada Kami; Sesungguhnya Engkaulah yang Maha mengetahui lagi Maha Bijaksana. ( Al-Baqarah : 31-32).

Berdasarkan ayat tersebut kita memahami firman Allah” Dan dia mengajarkan kepada Adam seluruh nama-nama" dalam arti bahwa Allah telah mengajarkan kepada Adam berbahasa. Menyebut nama-nama yang melambangkan konsep-konsep. Dengan belajar nama -nama benda benda dan dengan cara ini, telah mengajar tentang sifat dan karakter dari konsep tersebut, karena konsep-konsep tersebut tidak terlepas dari sifat dan karakternya masingmasing. Secara psikologis Proses belajar yang dilalui Adam as, sesungguhnya akan dilalui oleh semua anak cucunya. Pada dasarnya manusiapun tidak sepenuhnya mampu merespon semua objek yang ada disekitarnya, karena masing-masing itu berdiri sendiri-sendiri. Oleh karena manusia berupaya menyederhanakan konsep-konsep tersebut dengan cara mengumpulkan objek-objek yang mempunyai karakteritik yang sama dalam satu kelompok atau jenis tertentu seraya membentuk konsep tertentu, mengadakan nama tertentu dan memberikan respon tertentu.

2. Belajar Membaca.

Untuk mengetahui betapa pentingnya belajar bahasa dalam kehidupan manusia, alQur'an surat pertama kali yang diturunkan Allah mendorong kepeda manusia untuk membaca. Surat tersebut juga menunjukan karunia Allah kepada manusia atas kemampuannya belajar bahasa. Ditambah lagi dengan manusia mempelajari tulis baca, ilmu pengetahuan, keterampilan yang beragam, serta hal-hal yang tidak diketahui sebelum Allah menunjukan untuk mempelajari Ilmu yang telah dicapainya, sebagaimana firmannya:

Artinya: Bacalah dengan (menyebut) nama Tuhanmu yang Menciptakan, (1) Dia Telah menciptakan manusia dari segumpal darah (2) Bacalah, dan Tuhanmulah yang Maha pemurah, 
(3) Yang mengajar (manusia) dengan perantaran kalam (4) Dia mengajar kepada manusia apa yang tidak diketahuinya. (5).(QS. al-Alaq : 1-5)

Kewajiban belajar bagi manusia memlalui proses membaca, mendengar dan merasakan. Karena ketiga karakter tersebut ada pada diri manusia. Untuk mengajar manusia seorang guru dituntut untuk memahami psikologi peserta didik baik diri sifat maupun watak peserta didik (siswa). Dengan mengetahui sifat dan watak dari masing-masing peserta didik, seorang guru akan mudah memasukan materi ajar kepada siswa atau peserta didik.

Allah pun menyebautkan keistimewaan manusia, dibanding makhluk lain, lantaran kemampuan manusia dalam belajar dan menganalisa serta menggunakan bahasa untuk memperjelas gagasan-gagasan yang tersimpan di dalam diri manusia. Sesuai dengan firman Allah:

Artinya:Yang Telah mengajarkan al-Quran. Dia menciptakan manusia. Mengajarnya pandai berbicara.(Ar-Rahman: 2-4)

3. Belajar Memilih dan Membuat Keputusan.

Allah sesungguhnya berkehendak mengajari kedua manusia yang diciptakannya (Adam dan Hawa) tentang beberapa kebiasaan berprilaku yang bermanfaat dalam kehidupannya. Kebiasaan tersebut sesuai pula dengan sifat manusia yang diciptakan dari materi dan roh serta pergumulan yang kadang timbul dari seorang manusia antara tuntutan-tuntutan tubuh dan roh.

Allah mengajari kedua manusia yang diciptakan itu, cara memilih dan mengambil keputusan serta memikul tanggung jawab atas pilihan-pilihan yang dilakukannya dan keputusankeputusan yang dilakukannya. Hal tersebut diwujudkan dengan cara melarang keduanya mendekati sebuah pohon:

Artinya : Dan kami berfirman: "Hai Adam, diamilah oleh kamu dan isterimu di dalam surga ini, dan makanlah makanan-makanannya yang banyak lagi baik d imana saja yang kamu sukai, dan janganlah kamu dekati pohon ini, yang menyebabkan kamu termasuk orangorang yang zalim. Lalu keduanya digelincirkan oleh syaitan dari surga itu dan dikeluarkan dari keadaan semula dan kami berfirman: "Turunlah kamu! sebagian kamu menjadi musuh bagi yang lain, dan bagi kamu ada tempat kediaman di bumi, dan kesenangan hidup sampai waktu yang ditentukan." Maka Tuhan menerimanya (sebagai nazar) dengan penerimaan yang baik, dan mendidiknya dengan pendidikan yang baik dan Allah menjadikan Zakariya pemeliharanya. setiap Zakariya

\section{Al-Tarbawi Al-Haditsah: Jurnal Pendidikan Islam}

Vol. 3, No. 1, Juni 2018 
masuk untuk menemui Maryam di mihrab, ia dapati makanan di sisinya. Zakariya berkata: "Hai Maryam dari mana kamu memperoleh (makanan) ini?" Maryam menjawab: "Makanan itu dari sisi Allah". Sesungguhnya Allah memberi rezeki kepada siapa yang dikehendaki-Nya tanpa hisab.

Pengajaran yang dilakukan Allah kepada kedua manusia tersebut dalam upaya melatih dirinya dalam memilih dan mengambil keputusan. Dan apa yang dilakukan Allah kepada keduanya merupakan rencana dan rahsia Allah, dimana Adam dan Hawa sudah dipersiapkan untuk diturunkan kedua sebagai khalifah, karenanya kesuanya dipersiapkan untuk menghadapi berbagai situasai dan kondisi yang menuntut mereka untuk mengambil keputusan, sekaligus bertanggung jawab atas keputusan tersebut.

4. Cara-cara Belajar Menurut Al-Qur'an.

Pada dasarnya manusia belajar dengan caranya masing-masing, dan keinginan belajar itu merupakan sifat keingin tahu seseorang terhadap sesuatu melalui belajar dengan cara meniru atau Imitaition. Melalui pengalaman praktis atau trial and error, melalui pemikiran dan membuat konstruksi logis.

a. Meniru (imitaition)

Manusia banyak belajar dengan meniru atau Imitaition. Seorang anak akan meniru kedua orang tuanya dan saudara-saudaranya serta orang-orang yang dekatnya. Mereka selalu mencerna dan memperhatikan secara bertahap, dan menirunya secara pelan-pelan. Sebagaimana contoh yang diberikan dalam al-Qur'an ketika Habil membunuh Qabil, akan tetapi Habil tidak tahu harus diapakan Qabil yang sudah terbunuh tersebut. Kisah ini diabdikan Allah di dalam al-Qur'an.

b. Pengalaman praktis dan trial and error

Manusia juga belajar menghadapi dan mencoba mengatasi problematika kehidupan yang beragam melalui pengalaman praktis dan trial and error. Di dalam menjalani kehidupan manusia akan selalu berhadapan dengan situasi baru yang belum pernah dipelajari dan bagaimana merespon serta menykapi situasi baru dihadapan kita. Dalam Hal ini Rasulullah bersabda: " Jika hal itu memang bermanfaat bagi mereka, lakukanlah, sebab aku hanya mengira-mengira saja, dan kalian jangan sampai menyalahkanku berkaitan dengan perkara itu.Namun jika aku menyampaikan sesuatu dari Allah kepada kalian, maka 
terimalah, sebab aku tidk akan berkata, kalian lebih mengetahui tentang urusan dunia kalian.( HR. Muslim).

c. Berpikir

Manusia juga belajar melalui berpikir, ketika seseorang berpikir untuk memecahkan masalah tertentu, pada hakikatnya ia sedang melakukan semacam trial and error secara intelektual. Di dalam benaknya terlintas beberapa solusi atas suatu masalah. Ia akan menolak solusi yang salah sebaliknya akan memilih solusi yang dipandangnya tepat dan benar.

Firman Allah mengumpamakan sebagai mana disebutkan di dalam ayat berikut ini: Artinya :Maka apakah mereka tidak memperhatikan unta bagaimana dia diciptakan, dan langit, bagaimana ia ditinggikan? Dan gunung-gunung bagaimana ia ditegakkan?. Dan bumi bagaimana ia dihamparkan? (Al-Ghasyyah; 17-20).

5. Prinsip Belajar Menurut Al-Qur'an.

Proses belajar akan sempurna dan berhasil manakala prinsip -prinsip tertentu terpenuhi. Kadang-kadang, proses belajar itu mengalami sandungan. Kadang-kadang mengalami kegagalan bila prinsip tersebut tidak terpenuhi, apabila kita mempelajari metode yang dipergunakan dalam mendakwahkan keyakinan, mendidik kaum mukminin serta menanamkan prisip dan nilai-nilai keislaman pada diri mereka, niscaya kita dapat menggali beberapa prinsip penting, yang berkenan dengan proses pebelajaran yang digunakan al-Qur'an dalam mengubah prilaku kaum mukminin serta mengajar aqidah dan nilai-nilai keislaman kepada mereka.

Kita akan lihat bahwa prinsip-prinsip yang digunakan al-Qur'an dalam pembinaan ritual kaum mukminin itu, mengenai orgensinya dalam pembelajaran, baru diungkap pada psikolog awal abad ke 20M. Dalam ini al-Qur'an menjelaskan hal sebagai berikut: Motivasi, Pengulangan, Perhatian, Partisipasi Aktif. pembahagian Belajar, Perubahan Prilaku secara bertahap. ${ }^{18}$

${ }^{18}$ Muhibbin Syah, Psikologi Pendidikan dengan Pendekatan Baru (Bandug: PT Remaja Rosdakarya, 2008), 26. 


\section{F. KONSEP PEMBENTUKAN KARAKTER ANAK BERBASIS ISLAM}

Karakter anak berbasis islami haruslah dibentuk dan dididik sejak anak usia dini. Tujuannya agar anak mempunyai kepribadian yang baik sehingga ketika anak sudah menginjak dewasa nanti maka ia akan menjadi anak yang shaleh maupun shalehah sehingga akan bisa memberikan manfaat untuk masyarakat. Tanpa proses pemberian pengasuhan dan pendidikan yang benar, mustahil untuk mencetak anak yang berkarakter.

Pendidikan karakter ini merupakan segala upaya yang dilakukan oleh pendidik untuk mengajarkan kebiasaan cara berfikir dan berperilaku yang membantu anak untuk hidup dan bekerja bersama sebagai keluarga, masyarakat, dan bernegara dan membantu mereka untuk membuat keputusan yang dapat dipertanggung jawabkan, karakter juga dapat di istilahkan dengan tabiat, sifat-sifat kejiwaan, akhlak atau budi pekerti yang membedakan seseorang dengan orang lain. ( Adabul 'Alim wa al-Muta'allim, 2017. 29-33)

Menurut William Kilpatrick, dalam pendidikan karakter ada tiga komponen karakter baik yang harus dikembangkan dan merupakan ciri khas dari pendidikan karakter, yaitu pertama, moral knowing atau pengetahuan tentang moral, yaitu merupakan kesadaran tentang moral (moral awarenes), pengetahuan tentang nilai-nilai moral (knowing moral value), penentuan sudut pandang (perspective taking), logika moral (moral reasoning), keberanian mengambil dan menentukan sikap (decision making), dan pengenalan diri (self knowledge). Unsur moral knowing mengisi ranah kognitif mereka. Kedua, Moral feeling, yaitu merupakan penguatan aspek emosi siswa untuk menjadi manusia berkarakter. Penguatan ini berkaitan dengan bentuk-bentuk sikap yang harus dirasakan oleh siswa, yaitu kesadaran akan jati diri (conscience), percaya diri (self esteem), kepekaan terhadap derita orang lain (emphaty), cinta kebenaran (loving the good), pengendalian diri (self control), kerendahan hati (humility). Ketiga, moral Action, yaitu merupakan perbuatan atau tindakan moral yang merupakan hasil (outcome) dari dua komponen karakter lainnya.Untuk memahami apa yang mendorong seseorang dalam perbuatan yang baik (act morally) maka harus dilihat tiga aspek lain dari karakter, yaitu: kompetisi(competence), keinginan (will), dan kebiasaan (habit). ${ }^{19}$

19 Seto Mulyadi, Character Building: Bagaimana Mendidik Anak Berkarakter (Yogyakarta: Tiara Wacana, 2008), 30-31. 
Menurut T. Lickona, E. Schaps dan C. lewis (2003), pendidikan karakter harus didasarkan pada sebelas prinsip berikut ini:

a. Mempromosikan nilai-nilai dasar etika sebagai basis karakter.

b. Mengidentifikasi karakter secara komprehensif supaya mencakup pemikiran, perasaan dan perilaku.

c. Menggunakan pendekatan yang tajam, proaktif dan efektif untuk membangun karakter.

d. Menciptakan komunitas sekolah yang memiliki kepedulian.

e. Memberi kesempatan kepada siswa untuk menunjukan perilaku yang baik.

f. Memiliki cakupan terhadap kurikulum yang bermakna dan menantang yang menghargai semua siswa, membangun karakter mereka dan membantu mereka untuk sukses.

g. Mengusahakan tumbuhnya motivasi diri pada para siswa.

h. Mengfungsikan seluruh staf sekolah sebagai komunitas moral yang berbagi tanggung jawab untuk mendidik karakter dan setia pada nilai dasar yang sama.

i. Adanya pembagian kepemimpinan moral dan dukungan luas dalam membangun inisiatif pendidikan karakter.

j. Memfungsikan keluarga dan anggota masyarakat sebagai mitra dalam usaha membangun karakter.

k. Mengevaluasi karakter sekolah, fungsi staf sekolah sebagai guru karakter, dan manesfetasi karakter positif dalam kehidupan siswa.

Dalam pendidikan karakter, anak didik memang sengaja dibangun karakternya agar mempunyai nilai-nilai kebaikan sekaligus mempraktikkannya dalam kehidupan sehari-hari, baik itu kepada Tuhan Yang Maha Esa, dirinya sendiri, sesama manusia, serta lingkungan sekitar.

Anak yang berkarakter tentunya memiliki parameter dan nilai standarisasi meskipun pointnya bisa saja berbeda tergantung dari kemampuan yang dimiliki anak. Hal yang terbaik untuk digunakan sebagai parameter adalah tentunya pembentukan karakter anak yang 
berwawasan Islam. Dalam Islam sendiri mengatur tentang bagaimana cara membentuk karakter anak. Banyak acuan dan kisah-kisah yang bisa dijadikan media pembelajaran untuk membentuk karakter anak.

Dalam Al-Quran ataupun Sunnah Nabi banyak di jabarkan bagaimana cara membentuk dan mendidik anak sehingga anak bisa menjadi anak yang berkarakter. Karena pembentukan anak yang berkarakter mustahil dilakukan jika tidak ada contoh riil yang bisa dijadikan uswah atau teladan bagi anak. Teladan ini menjadi penting karena anak juga memerlukan figur sehingga ia akan mengikuti jalan yang pernah dilakukan oleh figur tersebut. Cara pembentukan karakter dimulai pada usia dini adalah dengan membentuk:

\section{Pola Pengasuhan (Hadanah)}

Karakter anak bisa dibentuk jika menggunakan pola pengasuhan yang benar. Anak-anak memiliki tahap-tahapan usia dan dalam tahapan usia tersebut tentunya anak juga memerlukan perlakuan yang berbeda. Cara mendidik anak ini akan bisa optimal jika disesuaikan dengan usia anak. Anak usia dini tentunya memerlukan kasih sayang yang cukup bila dibandingkan mendidik anak yang sudah memasuki usia dewasa. Penerapan ketegasan antara anak-anak akan berbeda dengan anak usia dewasa.

\section{Suri Tauladan}

Teladan sangat penting dalam proses pendidikan anak. Karena memang biasanya anak hanya akan meniru apa yang ada disekitarnya dan apa yang diajarkan kepadanya. Pembentukan karakter ini akan menjadi berat manakala tidak ada figur yang bisa dijadikan contoh terutama orang tua, karena orang tua merupakan contoh teladan terdekat anak.

\section{Rangsangan dan Ancaman}

Rangsangan dan ancaman hendaknya diajarkan kepada anak sehingga anak akan memiliki motivasi ketika beraktivitas. Pengenalan ancaman dan rangsangan ini bisa diajarkan secara bertahap sesuai dengan kemampuan berpikir anak. Dengan pemberian rangsangan maka anak akan termotivasi untuk berbuat kebaikan. Sedangkan pendidikan ancaman maka anak akan belajar untuk menjauhi dan tidak melakukan perbuatan buruk.

\section{Kisah Teladan}

Cerita merupakan kisah yang bisa memberikan nilai pendidikan untuk anak. Anak akan bisa menangkap maksud dari cerita yang di sampaikan tanpa ada kesan menggurui kepada anak. 
Agar nilai pendidikan bisa diserap anak maka sempatkanlah mendidik anak dengan membacakan kisah-kisah inspiratif untuk anak. Banyak cerita yang bisa kita sampaikan kepada anak baik itu kisah yang ada dalam Al-Qur'an ataupun cerita tentang Nabi dan sahabatsahabatnya.

\section{Dialog}

Komunikasi antara orang tua dengan anak sangat penting untuk dilakukan. Untuk anak usia dini, dialog yang baik akan bisa merangsang kemampuan bahasa anak. Dengan dialog dan komunikasi yang baik kepada anak juga akan mendekatkan hubungan orang tua dengan anak. Dialog yang baik akan menuntun anak dalam memahami karakter yang akan menjadi kepribadiannya. Maka tak heran dengan bahasa dialog kita akan bisa menebak seseorang darimana dia berasal. Dialog orang jawa tentunya juga akan berbeda dengan cara dialog orang batak.

\section{Latihan Pengamalan}

Sebuah teori ataupun pendidikan yang diberikan kepada anak juga harus diberikan contoh dalam pengamalan. Dengan melakukan aktivitas riil maka akan bisa membekas dalam ingatan anak sehingga tidak hanya sekedar retorika belaka yang tidak akan melekat dalam ingatan anak. Banyak contoh-contoh pengamalan sederhana yang bisa berikan.

\section{Lingkungan yang Mendukung}

Lingkungan merupakan pembentuk karakter anak yang cukup ampuh. Karakter anak sangat bisa dipengaruhi oleh kondisi lingkungannya. Teman bermain adalah magnet yang sangat kuat untuk anak meniru. Oleh karena itu agar anak memiliki karakter yang baik dibutuhkan lingkungan yang baik pula. ${ }^{20}$

Selain itu sekolah juga memiliki peran yang penting sebagai pendidikan formal yang diterima oleh anak, sekolah mengajarkan segala bentuk pendidikan akademik maupun non akademik melalui guru. Disini peran guru bukan sekedar memberikan pelajaran kepada peserta didik. Tapi lebih dari itu guru bertanggung jawab membentuk karakter peserta didik sehingga menjadi generasi yang cerdas, shaleh dan terampil dalam menjalani kehidupannya. Apalagi

\footnotetext{
${ }^{20}$ Seto Mulyadi, Seto, Character Building ............, 31-32.
} 
sekarang ini kehadiran guru semakin nyata menggantikan sebagian besar peran orang tua yang notabene adalah pengemban utama amanah Tuhan Yang Maha Esa. Dengan berbagai sebab dan alasan, orang tua telah menyerahkan bulat-bulat tugas dan tanggung jawabnya kepada guru disekolah dengan berbagai keterbatasannya.

Pada prinsipnya pembentukan karakter anak berhasil dan berjalan dengan lancar jika dilakukan secara benar dan menggunakan media yang tepat. Pendidikan karakter dilakukan setidaknya melalui berbagai media, yang diantaranya mencakup keluarga, satuan pendidikan, serta lingkungan yang baik. Dan untuk membantu suksesnya pembentuan karakter anak maka doa merupakan senjata yang ampuh yang wajib digunakan.

\section{G. Kesimpulan.}

Psikologi pendidikan modern dan Islam pada dasarnya dapat dipadukan, keduanya tidak jauh berbeda, sehingga ada kemungkinan untuk menggabungan antara keduanya. Sejumlah peristiwa dalam kehidupan Bernegara dan bermasyarakat banyak yang memberitan tindakantindakan seseorang remaja yang jauh dari moral baik dan akhlak seorang muslim. Dimana moralitas dan spiritualitas yang seharusnya menjadi bagian yang tak terpisahkan dari kehidupan psikologi manusia seakan-akan menjadi wacana yang asing dalam perkembangan psikologi. Fenomena ini membutuhkan alternatif baru guna mengembangkan dan menanamkan nilai-nilai keislaman yang sebenarnya. Salah satu solusi yang dianggap baik adalah dengan menghadirkan pembelajaran psikologi yang bernuansa agama. Yang betujuan untuk menanamkan nilai-nilai keislaman kepada generasi penerus bangsa agar terciptanya masyarakat dan negara yang tentram, aman dan nyaman.

Maka dari itu, karakter Islami adalah sesuatu yang sangat mendasar dan saling melengkapi. Masyarakat yang tidak berkarakter atau berakhlak mulia maka disebut sebagai manusia tidak beradab dan tidak memiliki harga diri atau nilai sama sekali. Karakter atau akhlak mulia harus dibangun, sedangkan membangun akhlak mulia membutuhkan sarana yang salah satunya adalah jalur pendidikan. Pendidikan bisa dilakukan di mana saja, tidak hanya di sekolah atau madrasah, akan tetapi juga di rumah (keluarga), maupun di masyarakat. Untuk menyegarkan kembali konsep pendidikan yang akan mampu membentuk karakter dan membangun akhlak mulia para peserta didik. 


\section{DAFTAR PUSTAKA}

Idris, Faridah. 2013. Membesarkan Anak Hebat dengan Susu Ibu. Malaysia: PTS Milenia SDN. Goleman, Daniel. 2002. Kecerdasan Emosional. Jakarta: Gramedia Pustaka.

Al Qur'an dan Terjemahannya. 1415H. Madinah: Mujamma' al Malik Fahd LiThiba'atal Mushaf.

http://www.duniapsikologi.com/emosi

Sopiatin, Popi dan Sohari Sahrani, 2011. Psikologi Belajar dalam Perspektif Islam. Bogor: Ghalia Indonesia.

Mukhtar, 2001. Konsep Diri Remaja. Jakarta: Rakastasmasta.

Nawawi, Syaikh Muhammad, bin Umar al-Bantani, 2011. Kasyifatus Saja. Beirut: Dar Ibn Hazm.

Herman, 2015. Remaja dalam Presfektif Pendidikan Islam. Jurnal Al-Izzah. Vol. 10 No.1.

Nata, Abudi. 2013. Filsafat Pendidikan Islam. Jakarta: Gaya Media Pratama.

Zuhairini, 2009. Filsafat Pendidikan Islam. Jakarta: Bumi Aksara.

Syah, Muhibbin. 2008. Psikologi Pendidikan dengan Pendekatan Baru. Bandug: PT Remaja Rosdakarya.

Mulyadi, Seto. 2008. Character Building: Bagaimana Mendidik Anak Berkarakter. Yogyakarta: Tiara Wacana. 